\title{
LUXURY FASHION CONSUMPTION AMONG YOUTH IN INDIA DURING AN ECONOMIC DOWNTURN: FACTORS AFFECTING ATTITUDE AND PURCHASE INTENT
}

\section{SHRIYA SINGH \& NISHI RANI}

Symbiosis Institute of Business Management (SIBM), Symbiosis International (Deemed University) (SIU), Electronic City, Hosur Road, Bengaluru, Karnataka, India

\begin{abstract}
In the ever changing era, quick adaptation of marketers with the changing times is increasing day by day. It has become pertinent to examine the behavior of consumers to stand the test of times and sustain in the competitive market. India's luxury fashion market has increased in the past few years but with uncertainties like an economic downturn we are faced with unprecedented situation.

The paper aims to find out the factors affecting luxury fashion consumption among the youth of India during an economic down turn. An empirical study was undertaken and attitude and purchase intention model was adopted from previous study. Data collection was done viaan online survey. 205 responses were collected and statistical tools such as SPSS and Excel were used for the factor analysis and application of correlation and regression for data analysis.

Through this research it came to light that brand consciousness, social comparison and fashion involvement affect the attitude of consumers who buy luxury fashion products. The attitude in turn impacts the final purchase intention of the buyer. The study can be further conducted for a larger population of consumers and on particular segment of luxury fashion goods like accessories, apparels, footwear and cosmetics.

KEYWORDS: Mineral, Cutting Fluids, Animal Fats, Vegetable Oils, Cutting Tools
\end{abstract}

Received: Jun 08, 2020; Accepted: Jun 28, 2020; Published: Sep 19, 2020; Paper Id.: IJMPERDAUG202030

\section{INTRODUCTION}

In the times of global calamity, amidst the economic downfall or situations like a pandemic, markets all over the world get stalled, the luxury sector has also witnesses a sudden change in the nature of functioning when within a blink of the eye, businesses are put on hold. A recent survey done by Mckinsey and company along with the Italian fashion chamber inferred that this pandemic will leave strong scars behind on the luxury sector. The question lies within searching for numerous opportunities that could be cherished well enough to sustain in this storm.

According to the survey the sales for luxury products globally are predicted to decline by $\$ 146$ bn in 2020 (Mckinsey 2020). The industry whose worth was somewhere around $\$ 438$ bn in 2019 , the analysis suggests that it would take one more year with this downfall to imagine about recovering in the post pandemic era.

The buying psyche is changing from 'conspicuous consumers to conscious consumers as seen in the China market which will be followed to India is strongly suggested by the fashion industry pundits. The online channel is expanding magnanimously and all the retailers and people tied around this chain have to adapt efficiently to the new ways of business sustenance. Statista states India's luxury goods segment which is relatively nascent to be around 
$\$ 8$ billion and forecasts 6.6\% CAGR growth during 2019-23. It is negligible compared with the US market which is \$62 billion in annual sales, and China, total value of $\$ 41$ billion.

The Indian environment for the luxury goods has faced multiple challenges such as demonetization, GST etc. to make it a difficult task for the key players in the industry to grow, yet after overcoming these obstructions, we have gained a solid ground in the luxury portfolio.

An article on "How to market in a Downturn" (John Quelch and Katherine E. Jocz 2009) published on HBR emphasizes on understanding the psychology of recession and then segmenting customers into four groups on the basis of consumer's emotional reactions. The four groups differ in their reaction towards change and their spending habits also change during the downturn.

This research paper will dwell down more into the intricacies of luxury market situation during an economic downturn as well as it would like to present a perspective on how can companies and businesses salvage the ruins and construct it back into up and running businesses by chasing hidden opportunities.

Luxury brands represent social, emotional and functional values for consumers. Consumers prefer luxury for various reasons. There are various factors which drive the consumer to choose a fashion merchandise. Perception of consumers about the luxury fashion brands is affected by social comparison with celebrities and friends. The material wellbeing and its importance as perceived by an individual also affect the purchasing intent. There could be change in the buying behavior as psychological factors could weigh in more.

In the paper by Zhang and Kim "Luxury fashion goods are defined as apparel, accessories, handbags, shoes, watches, jewelry, and perfume for which the mere use or display of a particular branded product brings prestige to owners, apart from any functional utility."

This study aims to know the perception of consumers towards luxurious brands and the impact of their attitude on their buying behavior when they have less purchasing power. It will try to understand the consumer's behavior towards luxury during economic downturn. Moreover, the paper will also try to figure out the purchase behavior towards luxury relating to their frequency of purchase and price sensitivity due to the prevailing conditions in the economy.

\section{REVIEW OF LITERATURE}

\section{Luxury Fashion Goods}

A standard meaning of the term luxury (Godey et al. 2009) luxury brands (De Barnier, Rodina, and Valette Florence 2006) is still lacking in the present times. However in different studies researchers have tried to define these terms according to their in depth study on these topics throughout the world. Luxury, is elaborated as a means of "refined enjoyment, of elegance, of things desirable but not essential" (Goody, 2006), is attracting increasing number of people all throughout the world.

Luxury goods form a significant part of the emerging social protocol in which it is identified and their value for self is determined by the visible brands that helps in dressing up a person (Husic and Cicic, 2009)

Romaniuk \& Huang (2019) in their paper "Understanding consumer perceptions of luxury brands" drew data from individuals in China and USA belonging to top $25 \%$ income category in their respective countries in three major 
Luxury segments of fashion, jewellery and watches found that usage of brand and luxury product attribute affects the responses from individuals. It shows how different positioning of luxury brand is important to attract the customers.

Atwal \& Williams (2017) in their study on "Luxury Brand Marketing - The Experience Is Everything" talks about luxury market meets potentials by a personal connection with consumers who get more triggered by experiences relating to the usage of the luxury product over anything else. They show a stark difference between the communication and connection with the consumer who prefers luxury merchandise.

Becker, Lee and Nobre (2018) wrote a paper on "The Concept of Luxury Brands and the Relationship between Consumer and Luxury Brands" and suggests Symbolic consumption by the consumers which will help marketers and brand strategist to formulate a brand setting for luxury products.

\section{Luxury Fashion Goods during Economic Downturn}

Ang, Leong and Kotler (2009) wrote a research paper titled "The Asian Apocalypse: Crisis Marketing for Consumers and Businesses in 2009" analyzing consumers from different Asian countries. There was a fall in consumer confidence and their behavior was studied in depth which encompasses several factors like delayed buying high involvement items, more focus on long term sustenance and functions of products, turning to local brands, reliance on informative rather than image based and buying at lower offer prices. Businesses face a shortage in their cash flow. At such oppressing times it is essential for them to create effective strategies like expanding into crisis resistant markets, introducing new product lines, controlling prices while improving present products and preparing better positioning.

The research paper on "Retaining the allure of luxury brands during an economic downturn. Can brand globalness influence consumer perception?" (Hasan, Mehmedović, Duverger in Apr 2015) investigates how consumer's perception is influenced by brand globalness during global recessionary times. The study finds out that glocalization may be necessary to compete with local brands. The strategy of the brand to position itself to move from luxury to quality can help. It suggests working on all the marketing mix elements to stand out. Mentioned in the paper, Recession taught luxury companies the importance of listening to their customers in terms of product design.

Grundey in 2009 conducted a research on "Branding strategies during economic crisis: avoiding the erosion" to evaluate marketing actions which should be appropriate during an economic downturn. The consumers are extremely price conscious and easily switch brands according to their convenience. The economic crisis inflicted various difficulties in the market system.. Different markets need tailor-made marketing actions to realise goals. Price war is not an optimum solution during these depressing economic times. Marketing techniques, branding and other resources should be efficient enough to reach every consumer.

Zhang and Kim (2013) studied the "Luxury fashion consumption in China: Factors affecting attitude and purchase intent" did an in depth study about the end users of fashion brands and their preference for the same. They show the factors that lead a consumer to ultimately make the final purchase decision. The study done across three cities in China after the financial crisis attempts to add more to the luxury fashion industry.

\section{Luxury Fashion Goods in India}

Eng, Yong; Bogaert \& Julie (2010) in their research on "Psychological and cultural insights into consumption of luxury Western brands in India" find that in the Indian society the influence of internal factor like psychology and external factor 
like culture play a major role in forming preferences for a purchase. The results imply that there is little inclination for common luxury preference, Indian consumers like to consume products which differentiate them from the society.

Jain, Roy \& Ranchhod (2015) in the study on "Conceptualizing luxury buying behavior: the Indian perspective" constructed a framework to depict the purchase behavior for luxury with cultural background, pre-purchase and after purchase buying behavior of individuals. Gender was pointed out as moderating behavior antecedents of purchase and post purchase behavior.

\section{RESEARCH GAP}

In the paper written by Bopeng Zhang, Jung-HwanKim in 2013 on "Luxury fashion consumption in China: Factors affecting attitude and purchase intent" it was found that the attitude affects the purchase intention of consumers in China in the luxury fashion market. Using the research model from this paper we have studied the luxury fashion consumption among youth in India considering a situation like an economic downturn and taking a bigger sample size to encapsulate a larger consumer.

The focus of consumer segment in our paper is on the youth belonging majorly to the age groups between 19-30 years. Understanding their mindset will help us establish better ways to capture a larger market in the luxury segment.

\section{OBJECTIVE OF STUDY:}

The objectives of the paper are as follows:

- To assess how factors like Brand Consciousness (BC), Materialism (Mt), Social Comparison (SC), Fashion Innovativeness (FIn), and Fashion Involvement (FInv) is related to consumer's attitude which in turn affects the purchasing intention towards luxury fashion goods during economic downturn.

- To find whether the frequency of consumption of luxury fashion goods is affected during an economic downturn.

\section{HYPOTHESIS DEVELOPMENT}

The study has adopted the model from a previous research paper authored by (Bopeng Zhang, Jung-HwanKim, 2013). The model helps us to understand the impact of factors like BC, Mt, SC, F In and F Inv on the attitude of the consumer which in turn affects their final purchase intention. Adoption of this model for consumers in India with respect to the luxury fashion market will help us understand their mindset even during an economic downturn.

Below is the research model adopted from (Bopeng Zhang Jung-HwanKim, 2013) for the study. 


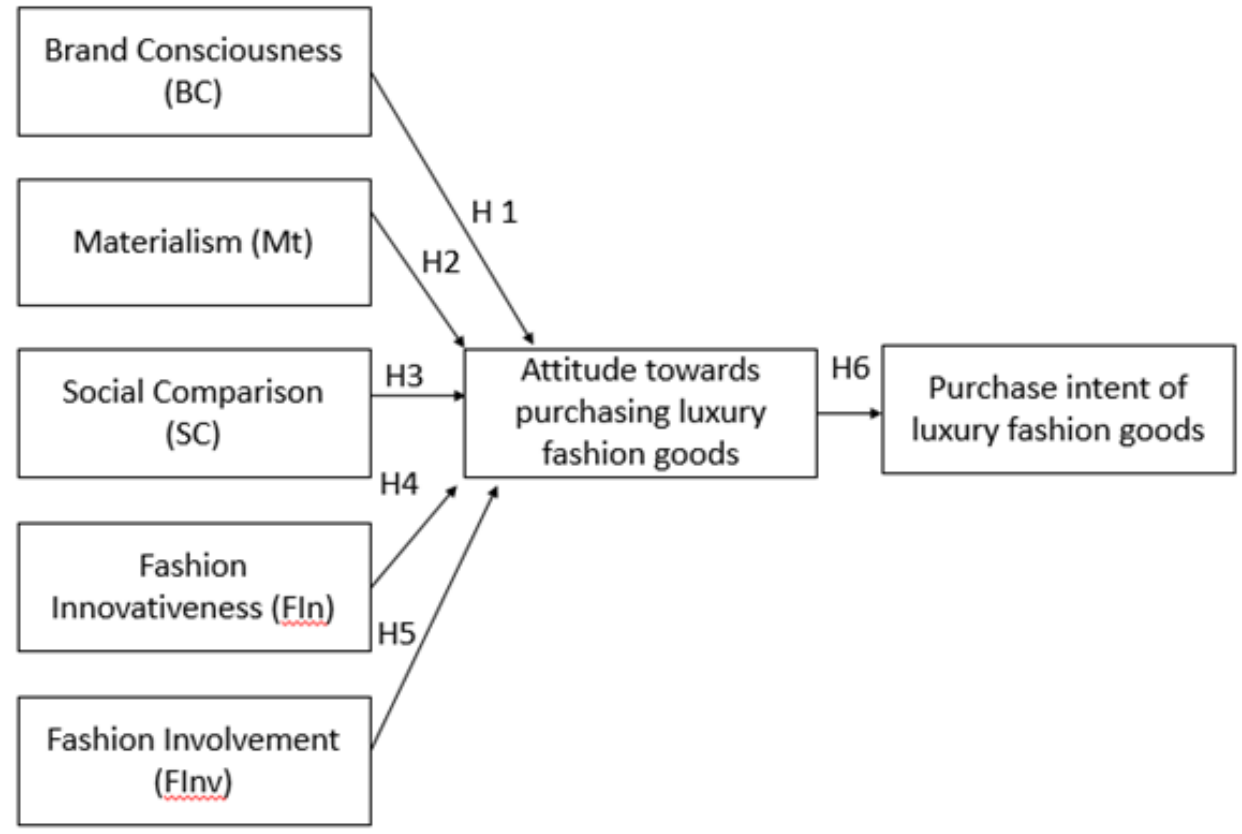

Figure 1

The hypothesis developed for the research:

- $\quad \mathrm{H}$ 1: There is a positive impact of BC related to attitude of consumers who purchase Lf goods.

- H 2: There is a positive impact of Mt related to attitude of consumers who purchase Lf goods.

- H 3: There is a positive impact of SC related to attitude of consumers who purchase Lf goods.

- $\quad \mathrm{H}$ 4: There is a positive impact of F In related to attitude of consumers who purchase Lf goods.

- H 5: There is a positive impact of F Inv related to attitude of consumers who purchase Lf goods.

- H 6: Attitude towards purchasing luxury fashion goods is positively related to purchase intent of Lf goods.

\section{METHODOLOGY}

Both primary and secondary source of data collection have been used for the study. Data collection by floating a questionnaire filled by the sample of the population was done for the study. Research Papers, Business reports, Books, Newspaper articles and other literature were reviewed for the purpose of research to set a fundamental understanding and further our knowledge in the domain. Saunders, Lewis and Thornhill (2009) in their analysis stated that surveys are a valid and appropriate tool for research as the researchers who have limited time and also due to economic reasons .Also it allows for the use of both inferential and descriptive statistics for hypothesis testing.

Hence our study would be using a survey to answer our research questions which would enable a bigger sample compared to other methods and an easy interpretation and comparison. 205 sample size is considered for the survey and this number of responses were collected. Convenience sampling has been used for the purpose of collecting the responses for the survey in this research. SPSS and Excel have been used to store and analyze data according to our study. 


\section{DATA ANALYSIS \& RESULTS}

To check the reliability and validity of the factors, factors analysis was done with the help of SPSS. The KMO values above 0.70 are considered to be middling (Backhaus, Erichson, Plinke and Weiber, 2006). In our model, the KMO value is 0.788 and the $\mathrm{p}$ value of the "Bartlett's Test of Sphericity" is significant at $99 \%$ confidence $(\mathrm{p}<0.001)$. Hence, the survey data for our study is appropriate for factor analysis.

The values in the diagonal of Anti-Image Correlation of the 6 factors taken into consideration was found to be between 0.653 and 0.875 , thus allowing the inclusion of all the variables in the analysis. The communalities describe the variance of the individual variables that can be understood better with the help of extracted factors. The standard value considered for the communality to fit the model is 0.5 . In our study, the communality for all the factors analyzed was above 0.5 except one variable of materialism. The value was dropped for the final analysis of the data.

The questionnaire underwent these tests to ensure that it is suitable for the factor analysis to be done to determine the validity and necessity of various factors and variables.

Table 1

KMO and Bartlett's Test

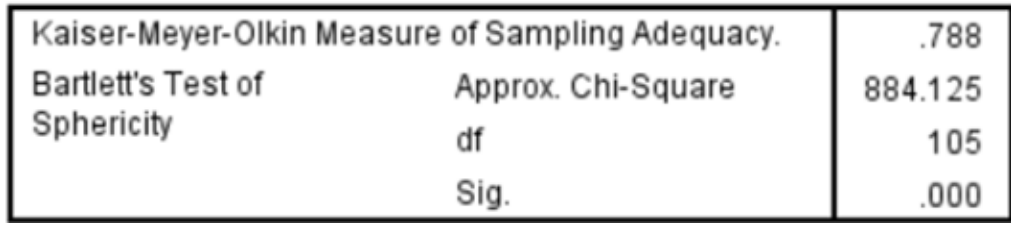

The table below represents the communalities done in the factor analysis:

Table 2

Communalities

\begin{tabular}{|l|c|r|}
\hline & \multicolumn{1}{|c|}{ Initial } & Extraction \\
\hline BC1 & 1.000 & .556 \\
BC2 & 1.000 & .699 \\
BC3 & 1.000 & .583 \\
Mt1 & 1.000 & .343 \\
Mt2 & 1.000 & .549 \\
SC1 & 1.000 & .691 \\
SC2 & 1.000 & .689 \\
FI & 1.000 & .673 \\
FIN1 & 1.000 & .662 \\
FIN2 & 1.000 & .725 \\
FIN3 & 1.000 & .708 \\
AT1 & 1.000 & .594 \\
AT2 & 1.000 & .566 \\
AT3 & 1.000 & .737 \\
AT4 & 1.000 & .859 \\
\hline
\end{tabular}

The below table represents the component matrix done in the process of factor analysis. There are 5 factors shown in the table. The grouping of variables which have similar range of values are clubbed together to form a factor. The five factors formed are FI, FInv, BC, SC and Mt. 
Table 3

Rotated Component Matrix ${ }^{\text {a }}$

\begin{tabular}{|l|l|l|l|l|}
\hline \multirow{2}{*}{} & \multicolumn{4}{|c|}{ Component } \\
\cline { 2 - 5 } & 1 & 2 & 3 & 4 \\
\hline FI & -.792 & & & \\
FIN3 & .752 & & & \\
FIN1 & .733 & & .433 & \\
BC1 & .715 & & .357 & \\
BC2 & & -.826 & & \\
BC3 & & .669 & & .394 \\
AT1 & & .550 & & .437 \\
AT2 & & .539 & .377 & .328 \\
AT3 & & & .814 & \\
SC2 & & & .728 & \\
SC1 & & -.430 & & -.721 \\
Mt2 & & & .403 & .570 \\
Mt1 & & & & .444 \\
\hline
\end{tabular}

Extraction Method: Principal Component Analysis.

Rotation Method: Varimax with Kaiser Normalization.

a. Rotation converged in 6 iterations.

\section{Results Obtained to Test the Hypothesis}

The analysis was performed on the 205 responses received from the online survey. The data was cleaned with the help of excel and made suitable for the further analysis. According to our hypothesis framed for the analysis of the study, two regression models were run with the help of SPSS to analyze the adopted model.

Table 4

\begin{tabular}{|l|c|c|}
\hline & Frequency & \%(approximately) \\
\hline Gender & & \\
\hline Male & 83 & $40.5 \%$ \\
\hline Female & 122 & $59.5 \%$ \\
\hline Age & & \\
\hline $19-23$ & 80 & $39 \%$ \\
\hline $24-30$ & 120 & $58.5 \%$ \\
\hline $31-40$ & 3 & $1.5 \%$ \\
\hline 41 and above & 2 & $1 \%$ \\
\hline Occupation & & \\
\hline Student & 146 & $71 \%$ \\
\hline Professional & 45 & $23 \%$ \\
\hline Business & 9 & $2 \%$ \\
\hline Other & 5 & \\
\hline $\begin{array}{l}\text { Money spent on luxury fashion } \\
\text { goods }\end{array}$ & & $20 \%$ \\
\hline Below Rs 1000 & 40 & $33 \%$ \\
\hline Rs 1000 -Rs 3000 & 70 & $23 \%$ \\
\hline Rs3000- Rs 5000 & 46 & $24 \%$ \\
\hline Rs 5000 and above & 49 & \\
\hline
\end{tabular}


The analysis was performed on the 205 responses received from the online survey. The data was cleaned with the help of excel and made suitable for the further analysis. According to the model adopted, (Bopeng Zhang , JungHwanKim, 2013) 2 regression models were run with the help of SPSS to test the hypothesis for the study.

Model run on SPSS to test the hypothesis is shown below.

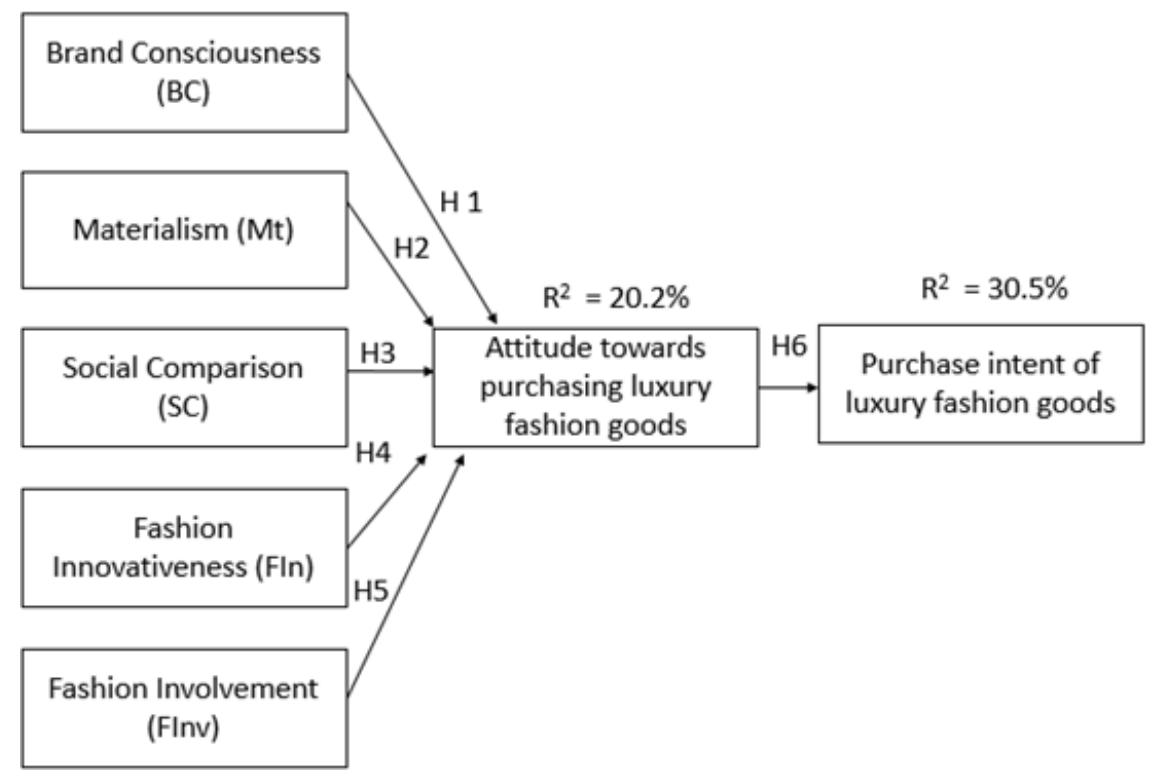

Figure 2

\section{Model 1}

- $\quad$ Attitude $=2.224+0.128(\mathrm{BC})-0.24(\mathrm{Mt})+0.126(\mathrm{SC})-0.13(\mathrm{~F}$ In $)+0.125(\mathrm{~F}$ Inv $)$

- Dependent Variable: Attitude

- Independent Variable: BC, Mt, SC, F In, F Inv

Table 5

\begin{tabular}{|l|r|r|r|}
\hline & \multicolumn{1}{|c|}{ Mean } & Std. Deviation & \multicolumn{1}{c|}{ N } \\
\hline Attitude & 3.202 & .6118 & 205 \\
Brand Consciousness & 3.334 & 1.0287 & 205 \\
Materialism & 3.373 & .8349 & 205 \\
Social Compariosn & 2.283 & .9965 & 205 \\
Fashion Innovativeness & 2.795 & 1.2434 & 205 \\
Fashion Involvement & 3.027642276 & .9971610693 & 205 \\
\hline
\end{tabular}

Table 6

Model Summary

\begin{tabular}{|c|c|c|c|c|c|c|c|c|c|}
\hline \multirow[b]{2}{*}{$\begin{array}{l}\text { Mode } \\
\text { I }\end{array}$} & \multirow[b]{2}{*}{$\mathrm{R}$} & \multirow[b]{2}{*}{$\begin{array}{c}\mathrm{R} \\
\text { Square } \\
\end{array}$} & \multirow[b]{2}{*}{$\begin{array}{l}\text { Adjusted R } \\
\text { Square }\end{array}$} & \multirow[b]{2}{*}{$\begin{array}{l}\text { Std. Error of } \\
\text { the Estimate }\end{array}$} & \multicolumn{5}{|c|}{ Change Statistics } \\
\hline & & & & & $\begin{array}{c}\text { R Square } \\
\text { Change }\end{array}$ & $\begin{array}{c}\mathrm{F} \\
\text { Change } \\
\end{array}$ & df1 & $\mathrm{df2}$ & $\begin{array}{c}\text { Sig. F } \\
\text { Change } \\
\end{array}$ \\
\hline 1 & $.470^{3}$ & .221 & .202 & .5466 & .221 & 11.312 & 5 & 199 & .000 \\
\hline
\end{tabular}

a. Predictors: (Constant), Fashion Involvement, Materialism, Fashion Innovativeness, Social Comparison, Brand Consciousness 
Table 7

\begin{tabular}{|c|c|c|c|c|c|c|c|c|}
\hline \multirow[b]{2}{*}{ Mode } & & \multicolumn{2}{|c|}{$\begin{array}{c}\text { Unstandardized } \\
\text { Coefficients }\end{array}$} & \multirow{2}{*}{$\begin{array}{c}\text { Standardized } \\
\text { Coefficients } \\
\text { Beta }\end{array}$} & \multirow[b]{2}{*}{$\mathrm{t}$} & \multirow[b]{2}{*}{ Sig. } & \multicolumn{2}{|c|}{ Collinearity Statistics } \\
\hline & & $\mathrm{B}$ & Std. Error & & & & Tolerance & VIF \\
\hline \multirow[t]{6}{*}{1} & (Constant) & 2.224 & .242 & & 9.177 & .000 & & \\
\hline & Brand Consciousness & .128 & .043 & .215 & 2.971 & .003 & .746 & 1.341 \\
\hline & Materialism & -.024 & .051 & -.032 & -461 & .645 & .801 & 1.248 \\
\hline & Social Comparison & .126 & .044 & .205 & 2.881 & .004 & .770 & 1.298 \\
\hline & $\begin{array}{l}\text { Fashion } \\
\text { Innovativeness }\end{array}$ & -.013 & .035 & -.026 & -.362 & .718 & .772 & 1.295 \\
\hline & Fashion Involvement & .125 & .051 & 204 & 2.466 & .014 & .572 & 1.748 \\
\hline
\end{tabular}

The impact of 5 factors i.e. BC, Mt, SC, F In and F Inv on attitude of the consumers towards Lf during economic downturn was established with the help of regression. The model summary shows that all the factors except Mt and F In have significant impact on attitude of the consumers. The BC (Beta=0.128, p < 0.05) was found to be significant. The SC (beta $=0.126, p<0.05)$ has significant impact. F Inv (Beta $=0.125, \mathrm{p}<0.05)$ is significant at $95 \%$ confidence interval. This validates the hypothesis H1, H3 and H5.

\section{Model 2}

- $\quad$ Purchase Intention $=1.575+0.446$ (Attitude)

- Dependent Variable: Purchase Intention

- Independent Variable: Attitude

Table 8

Descriptive Statistics

\begin{tabular}{|l|r|r|r|}
\hline & \multicolumn{1}{|c|}{ Mean } & Std. Deviation & N \\
\hline Purchase Intention & 3.00257452574 & 491051147710 & \\
& 5258 & 110 & 205 \\
Attitude & 3.202 & .6118 & 205 \\
\hline
\end{tabular}

Table 9

\begin{tabular}{|c|c|c|c|c|c|c|c|c|c|}
\hline \multirow[b]{2}{*}{ Model } & \multirow[b]{2}{*}{$\mathrm{R}$} & \multirow[b]{2}{*}{$\begin{array}{c}\mathrm{R} \\
\text { Square } \\
\end{array}$} & \multirow[b]{2}{*}{$\begin{array}{c}\text { Adjusted R } \\
\text { Square } \\
\end{array}$} & \multirow[b]{2}{*}{$\begin{array}{l}\text { Std. Error of } \\
\text { the Estimate }\end{array}$} & \multicolumn{5}{|c|}{ Change Statistics } \\
\hline & & & & & $\begin{array}{l}\text { R Square } \\
\text { Change }\end{array}$ & $\begin{array}{c}\mathrm{F} \\
\text { Change }\end{array}$ & df1 & df2 & $\begin{array}{c}\text { Sig. F } \\
\text { Change }\end{array}$ \\
\hline 1 & $.555^{\mathrm{a}}$ & .308 & .305 & $\begin{array}{r}.4093800117 \\
80747\end{array}$ & .308 & 90.515 & 1 & 203 & .000 \\
\hline
\end{tabular}

Table 10

\begin{tabular}{|c|c|c|c|c|c|c|c|c|}
\hline \multirow{2}{*}{\multicolumn{2}{|c|}{ Model }} & \multicolumn{2}{|c|}{ Unstandardized Coefficients } & \multirow{2}{*}{$\begin{array}{c}\text { Standardized } \\
\text { Coefficients } \\
\text { Beta }\end{array}$} & \multirow[b]{2}{*}{$t$} & \multirow[b]{2}{*}{ Sig. } & \multicolumn{2}{|c|}{ Collinearity Statistics } \\
\hline & & B & Std. Error & & & & Tolerance & VIF \\
\hline \multirow[t]{2}{*}{1} & (Constant) & 1.575 & .153 & & 10.312 & .000 & & \\
\hline & Attitude & .446 & .047 & .555 & 9.514 & .000 & 1.000 & 1.000 \\
\hline
\end{tabular}


Further, the impact of attitude of the consumers on the final purchase intention was established with the help of regression. The model summary shows that the adjusted R2value is $27.8 \%$. The attitude is found to have significant impact on the final purchase intention of the consumers (beta $=0.437, \mathrm{p}<0.05)$. This validates the hypothesis H6.

\section{CONCLUSIONS}

Increasing adoption of foreign brands and awareness about the prevailing fashion style has made the consumers more brand conscious and inclined towards luxury fashion consumption.

According to the results of this study, BC, SC and F Inv positively affect the attitude of buyers. A favorable change in these factors will cause a positive impact on the attitude of the consumer. Mt and F In on the other hand seems to be insignificant part of attitude.

The Indian consumers get gravitated towards luxury brands that are easily recognizable by society to establish one's status and thus affects their attitude for purchasing luxury good. Assertion of oneself and their social attribute takes place through brands (Liao and Wang, 2009).

Indian customers pay heed to the dressing style of their friends and famous celebrities and get affected by it. Marketing strategies adopted to cater to these customers can emphasize on getting famous celebrities to endorse their brands to have a more profound impact on customers.

Another strategy could be to target the high income people as consumers are affected by their peers and family.

Fashion involvement is also considered as an important factor amongst highly educated, youthful, and conscious consumers. They keep themselves well equipped with latest trends on social media. To cater to this segment of the target audience it is important to advertise and keep constant connection with consumers through these platforms. Attitude of the consumer forms the purchase intention to ultimately buy the luxury fashion goods.

Altogether this research will provide better knowledge of the booming Indian Luxury fashion consumption market. Moreover this research will become helpful resource for luxury fashion companies in building effective marketing strategies to set foot in the market. They will be able to make be better placed to make informed decisions and can therefore sustain in the competitive market.

\section{LIMITATION}

In our study there are certain resource constraints within this study. The size of the sample chosen for the study is limited due to availability. The other aspects of consumer's attitude and perception can be studied in depth for future studies. A comprehensive sample from different age groups belonging to older generation who have more purchasing power can be done. While working with these constraints, convenience sampling was used which has its own limitations. A cross sectional study over a greater time span can be undertaken to further enrich the knowledge for this particular subject. 


\section{APPENDIX}

\section{Demography}

Table 11

\begin{tabular}{|c|l|}
\hline S. No. & \multicolumn{1}{|c|}{ Questions } \\
\hline 1 & Name \\
\hline 2 & Age \\
\hline 3 & Gender \\
\hline 4 & Occupation \\
\hline 5 & $\begin{array}{l}\text { Money spent on luxury fashion goods Below Rs 1000 } \\
\text { Rs. 1000- Rs 3000 } \\
\text { Rs. 3000- Rs. 5000 } \\
\text { Rs. 5000 and above }\end{array}$ \\
\hline
\end{tabular}

\section{Other Factors}

Table 12

\begin{tabular}{|c|l|}
\hline S. No. & \multicolumn{1}{|c|}{ Questions } \\
\hline 1 & Will you prefer to buy non branded goods over branded ones due to an economic downturn? \\
\hline 2 & I will continue buying foreign luxury brands like Nike, Levis, Puma, UCB, H\&M, Zara etc. \\
\hline 3 & I will prefer the brand of my choice even if it is higher in price. \\
\hline 4 & Would your life be any better if you could afford to buy and own certain things that you do not have now? \\
\hline 5 & What do the things you own say about how well you are doing in life? \\
\hline 6 & I pay attention to what brands my favorite celebrities wear. \\
\hline 7 & I pay attention to what brands my friends buy. \\
\hline 8 & In general, I am the last in my circle of friends to know and adopt the latest fashion trends. \\
\hline 9 & My friends turn to me for advice on fashion goods \\
\hline 10 & I keep myself updated with the latest fashion trends on social media \\
\hline 11 & Fashion goods are a part of my lifestyle and I will continue buying them \\
\hline 12 & For me, Buying Luxury fashion goods during an economic downturn is preferable \\
\hline 13 & How likely are you to switch to brands which are giving more offers and discounts? \\
\hline 14 & Will you reduce your frequency of purchase for luxury fashion goods during an economic downturn? \\
\hline 15 & Will you continue buying luxury fashion goods during an economic downturn? \\
\hline
\end{tabular}

\section{REFERENCES}

1. Atwal, G. \&. (2017). Luxury brand marketing-the experience is everything!. . In Advances in luxury brand management . Palgrave Macmillan, Cham., (pp. 43-57).

2. Becker, K. L. (2018). The concept of luxury brands and the relationship between consumer and luxury brands. Kip Becker, Jung Wan Lee, Helena M. Nobre/Journal of Asian Finance, Economics and Business, 5(3), 51-63.

3. De Barnier, V. R.-F. (2006). Which luxury perceptions affect most consumer purchase behavior? A cross- cultural exploratory study in France, the United Kingdom and Russia. Proceedings des Congrés Paris-Venise des Tendences Marketing, Paris, 8 , 7.

4. Eng, T. Y. (2010). Psychological and cultural insights into consumption of luxury western brands in India. Journal of Customer Behaviour, 9(1), 55-75.

5. Goody, J. (2006). From misery to luxury. Social science information, 45(3), 341-435. Grundey, D. (2009). Branding strategies during economic crisis: avoiding the erosion. Economics \& Sociology,, 2(2), 9-22.

6. Husic, M. \&. (2009). Luxury consumption factors. Journal of Fashion Marketing and Management: an international journal. 
7. Jain, S. \&. (2018). Effect of value perceptions on luxury purchase intentions: an Indian market perspective. . The International Review of Retail, Distribution and Consumer Research, 28(4), 414-435.

8. Jain, V. R. (2015). Conceptualizing luxury buying behavior: the Indian perspective. Journal of Product \& Brand Management.

9. J ha, S. U. S. H. M. I. T. A., and AJAI KUMAR Singhal. "A recent study on attrition trends and retention p ractices in India: Issues and implications." International Journal of Human Resource Management and Research 4.2 (2014): 47-58.

10. Ko, E. C. (2019). What is a luxury brand? A new definition and review of the literature. Journal of Business Research, 99, 405-413.

11. Kotler, P. A. (2009). Principles of marketing: A global perspective. Prentice-Hall. Principles of marketing: A global perspective. Prentice-Hall.

12. Liao, J. \&. (2009). Face as a mediator of the relationship between material value and brand consciousness. Psychology \& Marketing, 26(11), 987-1001.

13. Phang, G. I. (2016). ). Antecedents to consumer intention to buy luxury brands. Malaysian Journal of Business and Economics $(M J B E)$.

14. Romaniuk, J. \&. (2019). Understanding consumer perceptions of luxury brands. International Journal of Market Research, 1470785319891109.

15. Saunders, M. \&. (2009). Research methods for business students. . Financial Times Prentice Hall, Edinburgh Gate, Harlow.

16. S iddiqui, Kalim. "Higher education in the era of globalisation." International Journal of Humanities a nd Social Sciences 3.2 (2014): 9-32.

17. T yagi, Anita. "Fiscal policy: as a stabilization tool for discretionary and non discretionary policies." International Journal of Economics, Commerce and Research (IJECR) 6.3 ( 2016).

18. Zhang, B. \&. (20(1), 68-79). Luxury fashion consumption in China: Factors affecting attitude and purchase intent. Journal of retailing and consumer services, 2013 